\title{
New Approach to Multi-Criteria Ranking of the Copper Concentrate Smelting Processes based on the PROMETHEE/GAIA Methodology
}

\author{
Ivica Nikolić ${ }^{1}$, Isidora Milošević ${ }^{1}$, Nenad Milijicí ${ }^{1}$, \\ Aca Jovanović ${ }^{2}$, Ivan Mihajlović ${ }^{1}$
}

${ }^{1}$ University of Belgrade, Technical Faculty in Bor, Management Department, Vojske Jugoslavije 12, 19210 Bor, Serbia

${ }^{2}$ University Educons, Project Management College, Bože Jankovića 14, Voždovac, 11000 Belgrade, Serbia

inikolic@tfbor.bg.ac.rs,imilosevic@tfbor.bg.ac.rs,nmilijic@ttbor.bg.ac.rs, aca.jovanovic@pmc.edu.rs, imihajlovic@tfbor.bg.ac.rs

Abstract: Although the production of copper and its usage has been known for thousands of years, the search for the optimal process of its production is still in progress. The removal of the negative impacts of a certain technology could cost more, over a period of time, than the initial investment in the selection of the optimal technology process which would consider these effects. Hence, the selection should be supported by the innovative and modern tools, such as the applying of the multi-criteria analysis. This paper presents the implementation of the PROMETHEE/GAIA methodology for the ranking of the appropriate technological pyrometallurgical smelting process for the copper concentrate based on the eleven parameters which recognize the economic, ecological and technical aspects of the technological process. The implementation of the multi-criteria decision-making presented in this paper can be deemed as a contribution to the decision making tools, that is, to the one who makes a decision on the selection of the appropriate technological facility for smelting of the copper concentrates. The decision-makers faced with the practical need of evaluating and selecting the most appropriate technological process for pyrometallurgical copper extraction will get the greatest benefit from this multi-criteria model. The innovative contribution of this paper is also presented in the obtained model which systematically analyzes the ecological, economic and technical parameters of the copper extraction process.

Keywords: technological process; pyrometallurgical processes; ranking, PROMETHEE/GAIA 


\section{Introduction}

Copper is one of the most important raw materials in the $21^{\text {st }}$ Century. The demand for copper and its production shows a countinuous growth year after year. Therefore, there is a constant need for the development of better scientific tools and new technologies for copper extraction. Therefore enabling the preservation of the beauty of nature and its diversity as well as to increase copper production and consumption [1,2]. These are the reasons for an evolutionary development of the technological processes in extraction of non-ferrous metals, especially copper extraction, in the last 50 years [3-5].

Copper can be produced by two basic procedures: pyrometallurgical and hydrometallurgical processes. In the Earth's crust, copper is usually presented in the form of copper - iron sulphide $\left(\mathrm{CuFeS}_{2}\right.$ - chalcopyrite; $\mathrm{Cu}_{5} \mathrm{FeS}_{4}$ - bornite) and copper sulphide ( $\mathrm{CuS}$ - covellite, $\mathrm{Cu}_{2} \mathrm{~S}$-chalcocite). It indicates that the use of pyrometallurgical processes is significantly higher than the use of hydrometallurgical treatments in obtaining copper. About $80 \%$ of copper, nowadays, has been produced by pyrometallurgical process $[2,6]$. Also, numerous improvements that have occurred in the previous periods, have led to increasing production infrastructure and capacity as well as to reducing negative impact on the environment [7-9].

Copper smelters around the world currently implement a great number of different pyrometallurgical processes for copper extraction $[6,10,11]$. The authors of this study believe that, in the course of the ranking and selection of the appropriate technological process for the pyrometallurgical copper extraction, it is necessary to make the selection based on the multiple parameters considered simultaneously. Systomaticly resulting in obtaining an insight into the economic benefits of the process as well as the environmental and technological benefits. Some technological procedures, apart from their economic performances, may have bad ecological indicators and impacts which are not in accordance with the norms of the World Health Organization (WHO) [12,13], which should be also considered.

This study has considered eight technological processes with the greatest application in pyrometallurgical copper extraction in the world $[6,11,14]$. Based on the largest representation of the available technology, the following technological procedures have been considered: Outokumpu flash smelting (in contemporary practice known as Outotec flash smelting); Ausmelt/Isasmelt lance; Inco Flash; Mitsubishi; Noranda; El Teniente; Vanyukov and Reverberatory process.

The motive for this research derived from the detailed investigation of the literature, based on which it was concluded that there is no research in the available literature analyzing systematically the ecological and technical parameters. Also, the methodology applied in this paper is not sufficiently represented in this field. The aim of this paper is to perform prioritization and 
selection of overall ranking indicators, for each of the given technologies, which have been done on the basis of the eleven selected relevant process parameters. The following parameters have been considered: concentrate amount in charge (t/day); $\mathrm{Cu}$ content range in the concentrate, i.e. the difference between maximum and minimum possible content in the concentrate that the chosen technology can process $(\%)$; $\mathrm{Cu}$ content in copper matte (\%); Fe content in copper matte (\%); production of waste slag ( $\mathrm{t} /$ day); production of copper matte ( $\mathrm{t} /$ day); campaign life (years); sulfur recovery (\%); copper recovery (\%); $\mathrm{Cu}$ content in waste slag (\%), and minimal $\mathrm{Cu}$ content in the concentrate.

The structure of this paper is the following: Section 2 presents a literature review of analysed methodologies; Section 3 gives summary of considered technological processes; Section 4 describes applied methodology and the obtained results; Section 5 provides the discussion of the results; the final section, Section 6, presents the conclusions with indicated contributions and plans for further research.

\section{Literature Review}

Based on a broad literature review, the authors have come to the conclusion that since 1950s and 1960s, when foundations of Multicriteria Decision Making Methodology (MCDM) methods have been developed, MCDM have been applied in many areas [15-20]. Many studies attempt to develope new MCDM models and techniques and in the past decades the development of MCDM techniques have accelerated and seem to continue growing exponentially [20]. One of the most used MCDM technique is Analytic Hierarchy Process (AHP) developed by Saaty (1980) [21]. Main advantages of this method are usability, flexibility, dealing with tangible and non-tangible attributes and comparing alternatives with relative ease [22]. However, the main flaws of the AHP method is that it does not include appropriately, a decision-maker's pattern of thinking. For that reason Van Laarhoven and Pedrycz (1983) proposed fuzzy AHP which appropriately include decision-maker's thinking, but fuzzy numbers are not a solution when decision makers are hesitant in defining membership functions [22, 23]. Later, various variants of the FAHP and AHP methods were developed. For example, Zhu et al., (2015) presented AHP method based on rough numbers to determine the weight of each evaluation criterion, while Radwan et al. (2016) extended the AHP method via the neutrosophic set because neutrosophic logic is able to deal with contradictions which are true and false at the same time and also might be capable of simulating the human thinking $[22,24]$. PROMETHEE method was developed by Jean-Pierre Brans (1982). Group of PROMETHEE methods includes PROMETHEE I for partial ranking, the PROMETHEE II for complete ranking, PROMETHEE III for ranking based on interval, PROMETHEE IV for complete or partial ranking of the alternatives when the set of viable solutions is continuous, 
the PROMETHEE V for problems with segmentation constraints, PROMETHEE VI for the human brain representation, the PROMETHEE GDSS for group decision making, PROMETHEE TRI for dealing with sorting problems and the PROMETHEE CLUSTER for nominal classification [25, 26].

Also, its application in the selection of technological processes in the industry is significant [27-30]. On the other hand, the application of the PROMETHEE/GAIA methodology in the field of pyrometallurgy is limited and can be seen through the work of the group of authors, Nikolic D. et al. (2009), which were rankingcopper concentrates according to their quality [5]. However, the application of this methodology in the field of pyrometallurgical process selection is very scarce. Especially when viewed through an adequate understanding of the technical and ecological aspects of the observed technological processes, at the same time.

\section{Summary of Considered Technological Processes}

A brief presentation of the main characteristics of each considered technological process for pyrometallurgical copper extraction, currently in use in smelters all over the world will be provided in this section.

\subsection{Outokumpu Flash Smelting (Outotec)}

Outotec process has had very successful development in the last 50 years, and today it is the most widely used process in copper and nickel production [6, 3537]. About $50 \%$ of total world copper and nickel production is obtained by this technological procedure. Outotec smelting technology has the leading position in the copper production based on its economy, adaptability, low energy consumption and high sulfur recovery. Sulfur recovery in this technology ranges from $94 \%$ to $99 \%$. Autogenous smelting process of the copper concentrates in this procedure, compared to the reverbatory furnace, which were mostly presented in the world plants until 1970s, has significantly better technical and economical indicators: more efficient utilization of sulphide energy from concentrate, higher metal and sulfur utilization and far better protection from $\mathrm{SO}_{2}$ and other harmful substances pollution $[6,10,38,39]$. According to available data, currently 21 smelting plants in the world use this technology [40].

\subsection{Ausmelt/Isasmelt Lance}

Ausmelt/Isasmelt is a simple and highly efficient production process of the ferrous metals. This process of continuous smelting of sulfide, copper and other 
concentrates and materials is a newer autogenous smelting process and is present in nine world smelters [10, 40, 41]. It was developed in Australia by Mount Isa Mines Limited and Australian Commonwealth Scientific and Research Organisation (CSIRO), and was introduced in commercial use in 1992 [6]. The basic smelting technology of Isasmelt/Ausmelt consists of a lance submerging into the melt from the furnace top (TSL-Top Submerged Lance). This technology occupies one of the leading position in the world for low production cost and it meets strict environmental standards [42].

\subsection{Inco Flash}

Commissioning INCO smelting furnace in 1952, the deficiencies of the dominant reverbatory furnaces were eliminated, in order to better utilize sulfide mineral from concentrate. It helped in reducing the energy consumption, improving ecological environment conditions and increasing copper utilization [2, 11, 36, 43]. Introducing this process in the industrial application unifies the stages of roasting and smelting. Also, by replacing oxygen with technical oxygen the amount of gases generated in the process is reduced up to 40 times, compared to the reverbatory furnace, improving the economy of the operation and the protection of the atmosphere. However, the main disadvantage of the technology, beside expensive and complex charge preparation, is the great consumption of electricity, required for the oxygen production, with 50\% participation in the total costs. Other significant ecological parameters are: sulfur utilization of average $93.6 \%$, production dust of 95 to 230 tons per day, quantity of waste gases of $35000 \mathrm{Nm}^{3} / \mathrm{h}$, whereas $\mathrm{SO}_{2}$ in waste gases is $70 \%[6,44,45]$.

\subsection{Mitsubishi}

Mitsubishi process is a process of autogenous continuous smelting of copper sulfide concentrates. This technological procedure is characterized by high $\mathrm{SO}_{2}$ utilization, which is removed through smelting and converting process and makes about $99.5 \%$, and is further directed into the sulfuric acid or liquid $\mathrm{SO}_{2}$ production, via electrostatic precipitator [46-48] Emission of harmful gases is also reduced as the transport of melted material (melt), from one aggregate into the other, is not performed in the smelting pots. Mitsubishi process of continuous copper concentrate smelting has been continuously modernized and improved which has led to increased environment protection. This procedure is used in smelting plant in Naoshima, Japan, with the capacity of 240000 tons of copper per year and Kidd Creek, Canada, with the capacity of 120000 to 150000 tons of copper per year. The advantage of this procedure is its flexibility related to the conventional copper concentrate smelting methods, due to its ability to process reversal and secondary materials of different kinds and composition [49, 50]. Beside reduced electricity consumption, other process parameters that have impact 
on environment are: production dust ranging from 60 to $67 \mathrm{t} /$ day, amount of waste gases of $500 \mathrm{Nm}^{3} / \mathrm{h}$, as well as $\mathrm{SO}_{2}$ in waste gases making 25 to $30 \%[6,10]$.

\subsection{Noranda}

Noranda Inc. is a mining metallurgical company located in Rouyn-Noranda, Quebec, Canada. Noranda process has been constantly improved. By using 34\% of oxygen enriched air, they have almost achieved autogenous process with the use of small amounts of fuel, where as the oxygen grade of $40 \%$ achieved fully autogenous smelting. However, this oxygen enrichment is the upper limit at which the rapid wearing of refractory lining of reactor was observed that threatened the stability of the entire aggregate [51, 52]. Significant parameters of this technological process that have an impact on an ecosystem are: specific consumption of fuel heat making 2321-2954 MJ/t of concentrate, sulfur utilization ranging up to $94 \%$, production dust $70-100 \mathrm{t} /$ day, waste gases of $55000 \mathrm{Nm}^{3} / \mathrm{h}$, as well as $\mathrm{SO}_{2}$ grade in waste gases ranging from 16-20\% [6, 10, 36].

\subsection{El Teniente}

Increasing of the mining capacities in Chile required increasing of smelting capacities, better energy utilization, modernization of smelting process and more economical production. Therefore, Teniente, presents an important technology for copper concentrate smelting and processing. Control of work process is more complex than with the other technologies. The complexity is caused by technological process characteristics [53]. Smelting process products that have great impact on environment are: sulfur utilization ranging from 90\%-98\%, production dust of $50 \mathrm{t} /$ day, amount of wast gases of $60000 \mathrm{Nm}^{3} / \mathrm{h}, \mathrm{SO}_{2}$ in outlet gases ranging $12 \%-25 \%[10,36,41,54-56]$.

\subsection{Vanyukov}

Vanyukov process is an intensive autogenous process of copper sulphide concentrates in a bubbling bath. After the extensive testing in semi-industrial and industrial conditions, the first furnace was commissioned in 1982, in smelter in Norilsk (Russia). Six furnaces of this kind were installed in the ex Soviet Union. The process was named after its author, academician, professor A. V. Vanjukovu, in 1988. Some characteristic of the technology are the following: sulfur utilization $90 \%$, production dust 0.5 to $0.9 \%$ per ton of charge, amount of waste gases 35000 $55000 \mathrm{Nm}^{3} / \mathrm{h}, \mathrm{SO}_{2}$ in waste gases $25-40 \%[6,10]$. Also, the advantage of this smelting process is a possibility of autogenous or semi-autogenous smelting of poor and rich copper concentrates with different additives (humidity 6-8\%), coarse and selective excavated rich copper ore, reversal material (coarseness to $50 \mathrm{~mm}$ ), 
fuel (lumpy coal) and flux, so the procedure is far more flexible than smelting processes in floating conditions $[11,41]$.

\subsection{Reverberatory Furnace}

Although this copper extraction technology has been mostly replaced in almost entire world by some of the above described ones, the authors of the study believed that it should also be taken into consideration, as it used to be the basic process for the pyrometallurgical $\mathrm{Cu}$ production. This traditional way of sulfide concentrates smelting is still used in the countries such as China (Changzhou; Jiangsu; Shuikoushan; Hunan; Wuhu; Anhui); Germany (Hettstedt); Hungary (Csepel); Iran (Sar Chesmeh), Romania (Zlatna); etc. [11, 40, 57, 58]. Mixing copper concentrate with fluxes in predetermined ratio which is calculated in advance forms the charge. Charge formed in this way, requires previous roasting process. Batch roasting process is an exothermic process and represents a partial oxidation of sulphides, wherein the amount of sulfur is reduced to the limit that ensures smelting of the rich copper matte. In the course of this process, at temperature of $650{ }^{\circ} \mathrm{C}-700{ }^{\circ} \mathrm{C}$ reaction of dissociation of higher sulphides into lower ones occurs, oxidation of sulfuric vapors into $\mathrm{SO}_{2}$ and partly oxidation of lower sulphides into oxides. [56, 59]. Oxdiation level and roasting speed depend on the excess air. The success of roasting process is measured by the degree of desulfurization which represents the ratio of removed sulfur related to the total sulfur grade of the charge. Roasting process products are calcine which further goes into the smelting process and gases containing 8\%-9\% of $\mathrm{SO}_{2}$ which are directed from reactor to cooling (spray cooling), cleaning (electrofilters), and, then, through pipelines to sulfuric acid plant. Previously roasted charge (calcine) is loaded telescopically into the reverbatory furnace. Smelting process is performed at high temperatures $\left(1550^{\circ} \mathrm{C}\right.$ in the focus of the flame) in more or less oxidizing atmosphere, and the smelting products are copper matte containing $35 \%-45 \%$ of copper, slag with $0.5 \%-1 \%$ of copper and gases with $0.5 \%-1.5 \%$ of sulfur dioxide $[41,56,60,61]$.

\section{Methodology and Results of Research}

\subsection{Data Collection}

Data used for analyzing and ranking technology presented in this study have been collected from the relevant literature [6, 10, 11, 36, 41, 44, 56, 62, 63]. Based on the analysed data from literature, the following criteria for ranking technologies have been selected: quantity of concentrate in charge, $\mathrm{Cu}$ content range in the 
concentrate, $\mathrm{Cu}$ content in the copper matte, $\mathrm{Fe}$ content in the copper matte, production of waste slag, production of copper matte, campaign life, sulfur utilization, copper utilization, $\mathrm{Cu}$ content in waste slag and minimal $\mathrm{Cu}$ content in concentrates.

The average value for each of the eleven parameters was taken for the analysis, from a large number of smelting plants operating these technologies. Multicriteria Decision Making Methodology (MCDM) was used for the ranking of the analized technological processes for the smelting of the copper concentrate, according to eleven parameters, applying Decision Lab 2000 software [6, 31-34]. The PROMETHEE method has been used in the study, within multi-criteria analysis, for the selection of the optimal technology, based on pre-defined criteria. Application of GAIA plane has provided the graphical interpretation of the PROMETHEE method, thus supporting the analysis of the given decision and selection problem visually.

MCDM methods provide mathematical models for ranking alternatives based on the selected criteria, clearly and transparently presenting ranking alternative results and synthesis of final results [64, 65]. PROMETHEE (Preference Ranking Organization METHod for Enrichment Evaluation) is a kind of MCDM method developed by J. P. Brans and its basic point is comparison based on alignement [66-68]. The main objective of the method selecting for ranking copper producting technologies is the fact that PROMETHEE takes into account inner relationships of all evaluation factors in the decision making process as well as alternatives valuating according to each determined criterion. In addition to all selected ranking criteria are quantitative, PROMETHEE method enables consideration of multiple criteria in incommensurable units [69], which is additional reason for this method selection. Ranking results obtained by PROMETHEE methodology are followed by graphic display of alternatives applying GAIA plane. Hence, the technology has been named in contemporary literature PROMETHEE GAIA. The number of the studies applying PROMETHEE GAIA method in their research is increasing year after year, which is confirmed by numerous publications $[64,65$, $67,68,70-76]$.

\subsection{Multicriteria Analysis for Copper Obtaining Technologies}

Data collected on the base of the available technical characteristics from analysed technological processes, have been found in the literature resources $[6,10,11,36$, $41,44,56,62]$. Given data present basis for multicriteria analysis of the actual technologies for copper obtaining. Collected values are results of eleven considered technical characteristics (criteria) analysed for each individual technology (alternative), and they form collection of baseline data for PROMETHEE calculations (Table 1). 
None of the parameters (criteria) used in this study, was given advantage related to other parameters, therefore weight coeffecients have been excluded as a part of multicriteria analysis to avoid subjectivity assignment and give preference to one technology over another [70-73].

PROMETHEE METHOD includes six potential preference functions enabling user to express differences on the base of minimal dissents [33, 34]. Research presented in this study, has used type 1 function (usual). Preference function usual has been selected as the best solution for describing the analysed data (all data are quantitative) [77]. Min/Max values orientations are based on the context of each considered technology characteristics and their potential impact on researched technologies (Table 2). Thus, evaluation matrix has been given in Table 2.

Table 1

Average values of parameters used for ranking copper extraction technologies

\begin{tabular}{|c|c|c|c|c|c|c|c|c|c|c|c|}
\hline Alternatives & 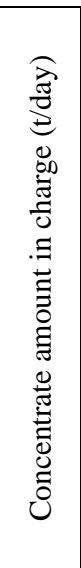 & 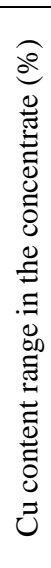 & 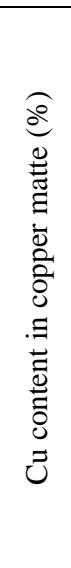 & 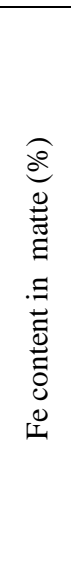 & 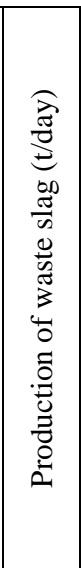 & 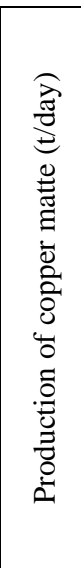 &  & 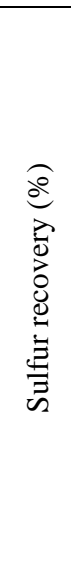 & 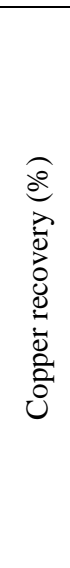 & 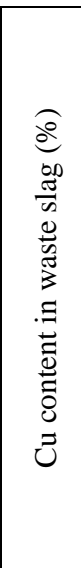 & 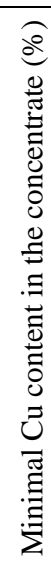 \\
\hline Outokumpu flash & 2750 & 5 & 65 & 11.5 & 2025 & 1500 & 9 & 96 & 97 & 0.65 & 26 \\
\hline $\begin{array}{c}\text { Ausmelt / Isasmelt } \\
\text { lance }\end{array}$ & 2250 & 4 & 67 & 14 & 1210 & 1200 & 2.1 & 97 & 97 & 0.6 & 25 \\
\hline Inco Flash & 3000 & 9 & 50 & 15 & 1350 & 935 & 15 & 93.6 & 97.5 & 0.65 & 20 \\
\hline Mitsubishi & 2150 & 6 & 71.5 & 7.75 & 1375 & 1209 & 3 & 99.5 & 97 & 0.75 & 28 \\
\hline Noranda & 2250 & 9 & 72.5 & 4.5 & 1500 & 975 & 1.75 & 94 & 95 & 0.75 & 28 \\
\hline El Teniente & 2300 & 7 & 73 & 4.5 & 1725 & 962.5 & 1.5 & 90 & 96 & 0.325 & 26 \\
\hline Vanyukov & 2150 & 8 & 59.5 & 10.5 & 1750 & 1300 & 4.5 & 90 & 98 & 0.6 & 26 \\
\hline Reverberatory & 2000 & 16 & 40 & 27.5 & 1050 & 1450 & 3.5 & 50 & 93 & 0.75 & 19 \\
\hline
\end{tabular}


Table 2

Preferences functions and Min/Max values orientations

\begin{tabular}{|c|c|c|c|c|c|c|c|c|c|c|c|}
\hline Criterion & 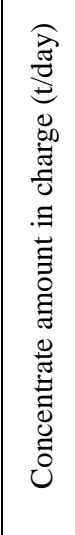 & 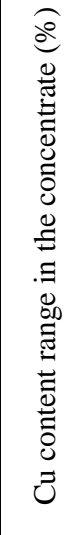 & 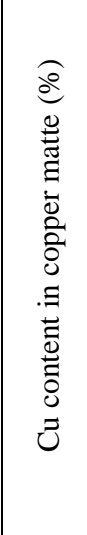 & 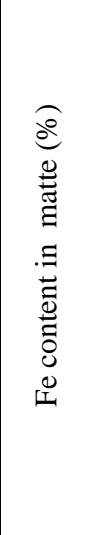 & 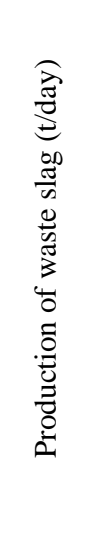 & 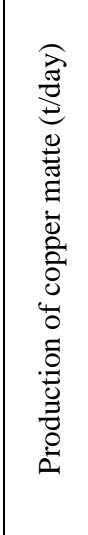 & 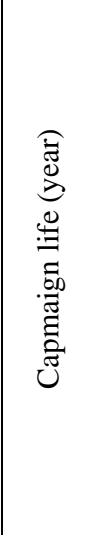 & 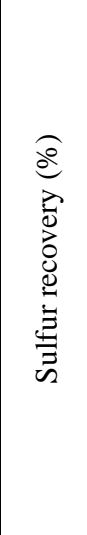 & 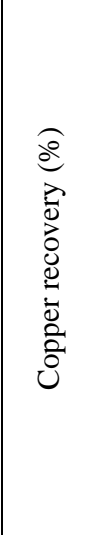 & 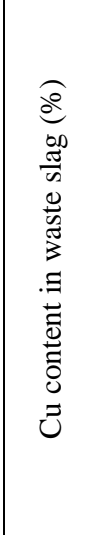 & 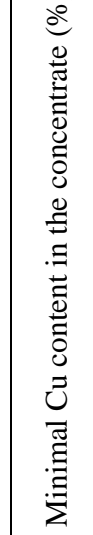 \\
\hline $\begin{array}{c}\text { Preferences } \\
\text { functions }\end{array}$ & Usual & Usual & Usual & Usual & Usual & Usual & Usual & Usual & Usual & Usual & Usual \\
\hline Min/Max & Max & Max & Max & Min & Min & Max & Max & Max & Max & Min & Min \\
\hline
\end{tabular}

Character of each criterion may be Max or Min and it is defined according to preset goals. For example, criterion concentrate quality in charge has been defined as Max, as greater values of given parameter realize economical production and have significant impact on better business results. Greater range of concentrate content flexibility will also provide better recovery, so character maximum value has also been used for this parameter. If the content range that can be technologically processed is greater, it implies that concentrates poor in ore could also be processed and the advantage is given to technologies that can melt concentrates with greater variation of copper grade. Copper grade in copper matte is defined as a parameter requiring higher value, hence it is also defined Max. Also, reactor lining repair (campaign life) is also defined max, as better lining cooling and longer campaign life are increasing economy of the process. Sulfur and copper recovery are also defined as max, from economical reasons as well as from ecological reasons. Character of other parameters has been defined as Min. The tendency is to keep Fe content in copper matte as small as possible to get the higher copper content, which requires less scope of further rafination. Also, $\mathrm{Cu}$ content in slag should be at the lowest possible level to obtain the best possible copper recovery Priority is given to smelters with possibility to melt poor concentrates, hence parameter of minimal $\mathrm{Cu}$ content in concentrate has been defined as Min. [5, 78, 79]. Multicriteria comparative analyses of copper obtaining technologies has been performed by using the software package Decision Lab 2000 [5, 34, 79]. Main screen of the software package Decision Lab 2000 is presented in Figure 1. 


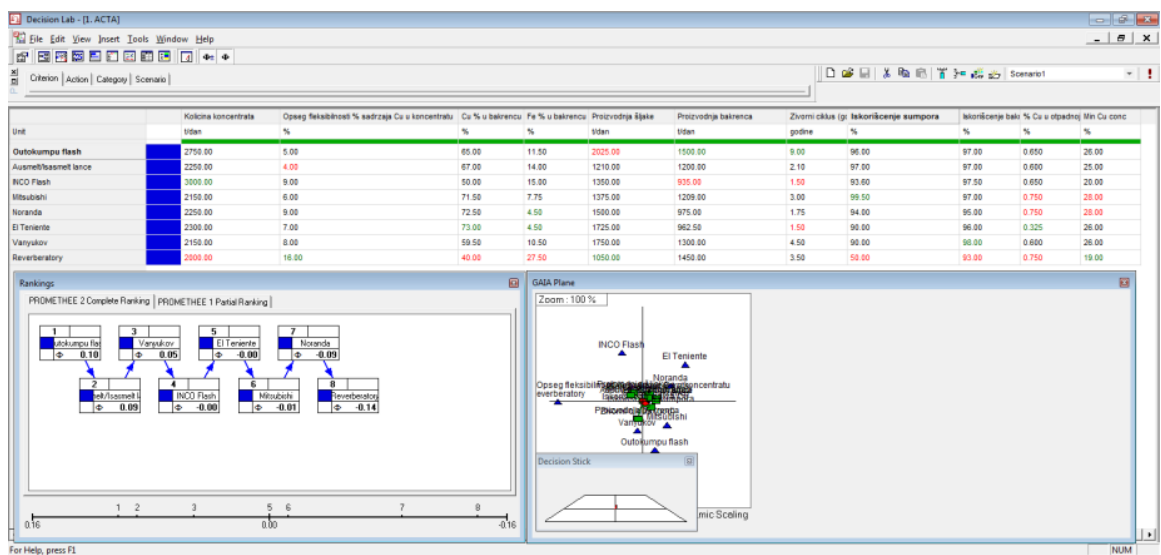

Figure 1

Main screen of the software package Decision Lab 2000

PROMETHEE method is based on determination of positive $\left(\phi^{+}\right)$and negative flow ( $\phi-)$ for each alternative. Positive preferance flow shows to what extent certain alternative dominates over the other alternative. The higher the value is $(\phi+\rightarrow 1)$, the alternative is more significant. Negative preferance flow shows to what extent certain alternative is preferred by other alternatives. Alternative is more significant if the flow value is less $(\phi-\rightarrow 0)$. Entire ranking within PROMETHEE II is based on calculating netto flow ( $\phi)$, which presents difference between preference positive and negative flow. Alternative with the highest netto flow value is best rated, and the one with the lowest netto flow is the worst rated [69, 80, 81]. Complete ranking (PROMETHEE II) of eight copper obtaining technologies was performed on the base of the given data and alternative values (technical characteristic for each researched copper obtaining technology, given in Table 1). Obtained results are given in Table 3 and Figure 2.

Table 3

Results of complete ranking of copper obtaining technologies based on PROMETHEE II MCDM method

\begin{tabular}{|l|l|l|l|l|}
\hline Rang & Alternative & $\Phi^{+}$ & $\Phi^{-}$ & $\Phi$ \\
\hline 1 & Outokumpu flash & 0.5195 & 0.4156 & 0.1039 \\
\hline 2 & $\begin{array}{l}\text { Ausmelt / Isasmelt } \\
\text { lance }\end{array}$ & 0.5195 & 0.4286 & 0.0909 \\
\hline 3 & Vanyukov & 0.4935 & 0.4416 & 0.0519 \\
\hline 4 & Inco Flash & 0.4805 & 0.4805 & 0.0000 \\
\hline 5 & El Teniente & 0.4675 & 0.4675 & 0.0000 \\
\hline 6 & Mitsubishi & 0.4545 & 0.4675 & 0.0130 \\
\hline 7 & Noranda & 0.4156 & 0.5065 & -0.0909 \\
\hline 8 & Reverberatory & 0.4156 & 0.5584 & -0.1429 \\
\hline
\end{tabular}




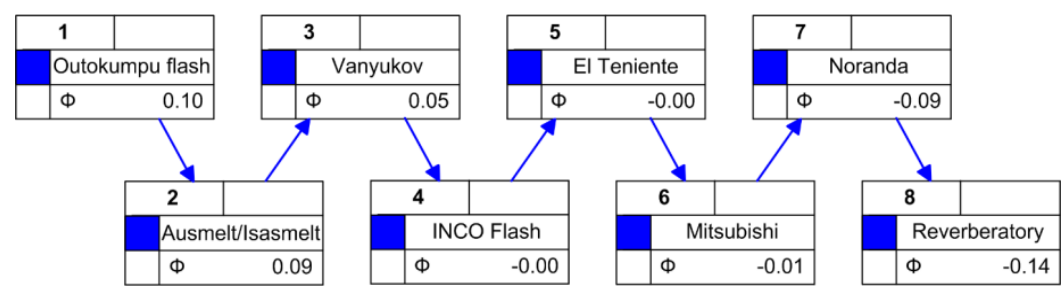

Figure 2

PROMETHEE II complete alternative ranking (technologies for pyrometallurgical copper extraction)

Very significant benefit of applying PROMETHEE methodology using Decision Lab, is visualization of obtained results, i.e. solution ranking by GAIA (Geometrical Analysis for Interactive Aid) plane. GAIA plane and results obtained by it, facilitate evaluation of obtained solutions as well as interpretation of significance of the individual variables. GAIA analysis provides important information on ranking within two-dimensional space, obtained by PCA extraction. This way, it is possible to display issues of conducted ranking graphically, to determine specific relationship characteristic between the selected alternatives. Positions of alternatives considered (triangles) determine strengths or weaknesses of activity properties related to selected criteria, determining future result of conducted final ranking. As the alternative is closer to criterion vector direction, it has a better value for the criterion [80, 82]. Figure 3 shows position of the considered alternative on GAIA plane. 


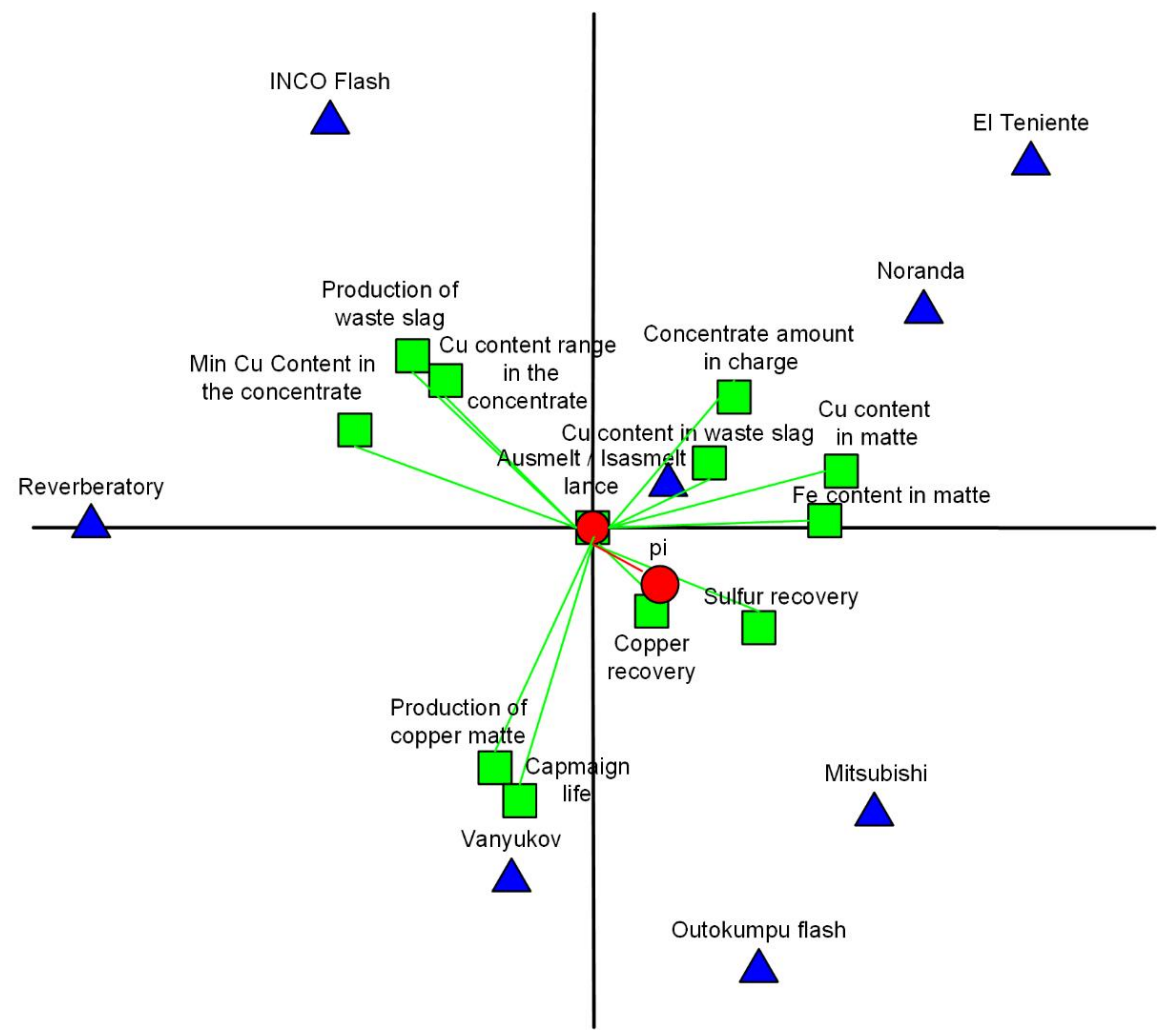

Figure 3

GAIA plane selection of the most appropriate alternative (copper obtaining technology)

\section{Results Discussion}

Based on the collected technical characteristics of copper obtaining technologies considered, it is obvious that it is possible to perform ranking of these characteristics (criteria) simultaneously. It means that application of multicriteria analysis enables multi-criteria ranking, list of priorities and thorough analysis of the problem. Data given in Table 1 were analysed that way, applying software package Decision Lab 2000. The results of the complete PROMETHEE II ranking are shown in the Table 3 and Figure 2. Visual presentation of the ranking is presented in Figure 3, providing comparison of all alternatives per a criterionGAIA plane. Percentage of the data collecting on GAIA plane, i.e. reliability of graphic interpretation is greater than $60 \%$ ( $\Phi: 70.19 \%)$, which is considered as very acceptable [80]. 
Position of the alternative (triangles on GAIA plane) determines its strengthen or weakness related to the criteria. If alternative is closer to the axis direction of a criterion, the alternative is a better option for the given criterion. Hence, Outokumpu flash technology has the best performances, as the alternative is the closest to the axis direction of the criterion with the greatest impact and positioned very close to axes of other criteria as well, unlike the most other alternatives. Vector pi (stick decision) is presented in the form of axe ending in circle and is an optimal solution according to given weight criteria. The best decision is the one closest to stick decision (Outokumpu flash), whereas the worst alternative is Reverberatory which is good at no criteria (except the possibility of processing poor concentrates), and it is located opposite of the stick decision direction.

Observing eccentricity of criteria positions (axes ending in square), i.e. their distance from the coordinate origin, it is obvious that criteria Utilization of $\mathrm{Cu}$, Utilization of $\mathrm{SO}_{2}$ and $\mathrm{Fe}$ in matte have greater impact related to other eight criteria. Additionally, they are closest to stick decision pi, which is confirmed by their greatest impact at alternative ranking. Taking into consideration that relatively great number of criteria have been used, their quality may be assessed as a satisfactory, as there are no expressed conflicts between them (there are no two criteria positioned opposite one another on GAIA plane.

As the ranking of technological process in this study, were based on the technical criteria, such result could have been expected, based on the collected data set. Outokumpu technology (ranked on the top) is characterized by autogenous continual smelting of sulfide copper and other concentrates and materials, and belongs to the group of the latest autogenous smelting processes. This technology is one of the leading technologies in the world for the low production costs and meets strict environmental standards. Opposed to it, Reverberatory technology has been ranked at the bottom for its poor technical characteristics $(\mathrm{Cu}$ in matte $=56.50 \%$; $\mathrm{Fe}$ in matte $=15.00 \%, \mathrm{Cu}$ in slag $=1.20 \%$ ). Therefore, these are the reasons why it has been almost completely suppressed, and is still being used in just few smelters in the world.

Noranda technology also has very poor performances whereas Mitsubishi, INCO Flesh and El Teniente, have no significant positive performances (Noranda has significantly negative and Mitsubishi negative flow value $\Phi$, whereas INCO Flesh and El teniente has neto flow value $\Phi$ near to 0 - Table 3 and Figure 2). The primary reason for such ranking of Norande and Mirtsubishi technologies should be found in the fact that they mostly process concentrates with high $\mathrm{Cu}$ content and create waste dross with increased $\mathrm{Cu}$ content. On the other hand, Inco flesh has been relatively poorly ranked for low $\mathrm{Cu}$ content in copper matte, low productivity of copper matte and short operation life. The similar situation is with $\mathrm{El}$ teniente technology which additionally has low total $\mathrm{Cu}$ recovery.

Based on their technical characteristics, Ausmelt/Isasmelt and Vanyukov technologies are ranked relatively satisfactory (positive netto flow values $\Phi$ ). 
Ausmelt/Isasmelt technology is ranked (positioned) positively according to the following criteria: $\mathrm{Cu}$ in slag, Utilization of $\mathrm{Cu}$, Concentrate Quantity in charge, $\mathrm{Cu}$ in matte and $\mathrm{Fe}$ in matte. They, actually, explain satisfactory performances of those technical characteristics at Ausmelt/Isasmelt technology. Besides, the possibility for improving technical performances of this technology for copper obtaining is in the fields Campaign life, Matte production and $\mathrm{Min} \mathrm{Cu}$ in concentrate. Based on the obtained results, the very interesting data is that, contrary to Ausmelt/Isasmelt technology, Vanyukov technology has been ranked (positioned) positively according to the criteria Campaign life and Matte production. Slag production, Range of $\mathrm{Cu}$ content flexibility in concentrate, Min $\mathrm{Cu}$ in concentrate and Content Quantity in charge are potential fields for improving performances of Vanyukov technology.

Finally, El teniente and Mitsubishi alternative position on GAIA plane, indicate that it is possible to achieve improvement of the technical characteristic performances of these technologies by improving any of considered technical characteristics for their low negative netto flow falue $\Phi$. On the other side, improving positions of Reverberatory furnace technology, or even Noranda technology, would require entire modification of values for almost all considered operational parameters, as negative netto flow values $\Phi$ are significantly great for these two technologies.

\section{Conclusion}

Copper production presents one of the primary activities in the sector of industry. It is energetically intensive and therefore it is positioned on the third place according to consumption of the specific energy, considering production of five base metals [83-85]. For this reason, it is necessary to conduct performing analysis of the available technologies for copper production and propose their further improvement. The fact is that technologies for pyrometallurgical copper extractions from sulfide type concentrates have evolved and are still evolving with the aim to optimize technical and economical as well as ecological process parameters. That is the reason why this study has analysed current copper extraction technologies and performed their multicriteria ranking.

The study is based on prioritization and selection of observed technologies whereas the selection has been performed according to the average values of the chosen eleven parameters. Most technologies considered in the study are based on copper concentrate autogenous smelting process starting from requirement for integration of particular processing stages (roasting, smelting, converting). Many leading companies dealing with copper production, have developed their own copper concentrate autogenous smelting processes which differ technologically and operationally. Also, there is a small number of companies still operating with technical processes which are not autogenic (as a reverberatory furnace). Those are the reasons why both kind of processes have been analysed. 
Multicriteria comporative data analysis used in this study, has provided significant conclusions on ranking and possible selection of the optimal technology for copper concentrate smelting, performed on the base of the eleven selected parameters belonging to the group of technical and ecological indicators. Moreover, multicriteria analysis explicitly emphasizes all key elements, that mostly influence the final prioritization result. The best ranked Outokumpu flash technology has totally best performances. If only individual ranking parameters were taken into account, this technology would have advantage over all others for the great quantity of produced copper matte and long campaign life. However, it has been the best ranked technology considering impact of all factors simultaneously, which is the aim of multicriteria analysis presented in this study.

Contribution of this research is in the systematical approach, in analysing of actual smelting technologies, by using MCDM methodology. Also, another contributioin is in developing the apropriate basis for development of the MCDA approach, that can be used in selection of the optimal smelting technology, based on the combination of input parameters, which is also partially filling the research gap in this field. This way, besides scientific contribution, presented methodology can be useful to decision makers, i.e. representatives of companies dealing with copper smelting process, as a good tool in the process of selecting the optimal technologies, based on different criteria they want to take into consideration.

The essence of this work is to present possibility of applying method MCDM as a useful support in decision making process, to decision maker dealing with ranking and selecting copper extracting technologies. Normally, the study has presented average parameter values from different world smelters, used by the given technologies. However, the same method could be used in realistic business environment in decision making processes based at real technological process parameters. Besides, the study implies that all criteria has the same weight coefficient value. But, if potential decision makers in the specific actual conditions consider that, e.g. ecological parameters are of greater importance (such as $\mathrm{SO}_{2}$ utilization), they can appoint this parameter with greater weight coefficient than other parameters. That will be the subject of further research that will include interviewing experts in the respected field on importance of each of 11 analysed parameters, and weight parameters of new ranking will be appointed according to the obtained opinions. There is also an interesting example from RTB Company Bor (Serbia) [86], when, in 2013 a group of experts from respected field of metallurgical sciences were included in selection of a new technology to replace the reverberatory furnace that had been in operation until then. Outokumpu technology was selected according to the opinion of experts clearly demonstrating that presented selection and results of multicriteria analysis given in this study has practical stand-fast.

\section{Acknowledgement}

The authors feels indebted to the company Visual Decision Inc. Montreal, Canada; for software package Decision Lab 2000 provided to them free of charge. 
Part of this research is financially supported through the project of the Ministry of Education, Science and Technological Development of Serbia - TR34023

\section{References}

[1] Sievers H, Meyer FM. Parameters influencing the efficiency of copper extraction. Erzmetall. 2003;56(8): pp. 420-425

[2] Požega E, Gomidželović L, Trujić V, Živković D. Analysis of advanced technologies in copper metallurgy. Copper. 2010;35(1): pp. 15-24

[3] Herreros O, Quiroz R, Manzano E, Bou C, Vinals J. Copper extraction from reverberatory and flash furnace slags by chlorine leaching. Hydrometallurgy. 1998;49(1-2): pp. 87-101

[4] King GM. The evolution of technology for extractive metallurgy over the last 50 years - is the best yet to come? JOM. 2007;59(2): pp. 21-27

[5] Nikolic D, Jovanovic I, Mihajlovic I, Zivkovic Z. Multi-criteria ranking of copper concentrates according to their quality - An element of environmental management in the vicinity of copper - Smelting complex in Bor, Serbia. J. Environ. Manage. 2009;91(2): pp. 509-515

[6] Schlesinger M, King M, Sole K, Davenport W. Extractive Metallurgy of Copper (Fifth edition). Amsterdam (NL): Elsevier; 2011

[7] Franzin WG, McFarlane GA, Lutz, A. Atmospheric fallout in the vicinity of a base metal smelter at Flin Flon, Manitoba, Canada. Environ. Sci. Technol. 1979;13(12): pp. 1513-1522

[8] Filipou D, St.German P, Grammatikopolus T. Recovery of metal values from copper - arsenic minerals and other related resources. Miner. Process. Extr. Metall. Rev. 2007; 28: pp. 247-298

[9] Aznar JC, Richer-Lafleche M, Cluis D. Metal contamination in the lichen Alectoria sarmentosa near the copper smelter of Murdochville, Quebec. Environ. Pollut. 2008;156(1): pp. 76-81

[10] Davenport W, King M, Schlesinger M, Biswas A. Extractive Metallurgy of Copper (Fourth edition). Amsterdam (NL): Elsevier, 2002

[11] Moskalyk R, Alfantazi A. 2003. Review of copper pyrometallurgical practice: today and tomorrow. Miner. Eng. 2003;16: pp. 893-919

[12] Nikolic D, Milošević N, Mihajlović I, Živković Ž, Tasić V, Kovačević R, Petrović N. Multi-criteria Analysis of Air Pollution with SO2 and PM10 in Urban Area Around the Copper Smelter in Bor, Serbia. Water, Air \& Soil Pollution. 2010;206: pp. 369-383

[13] WHO (World Health Organization), 2015. WHO Expert Consultation: Available evidence for the future update of the WHO Global Air Quality Guidelines (AQGs) Regional Office for Europe, Bonn, Germany 
[14] Jovanović I, Stanimirović P, Živković Ž. Environmental and economic criteria in ranking of copper concentrates. Environ. Model. Assess. 2013;18(1): pp. 73-83

[15] Badi I, Ballem M,Supplier selection using the rough BWM-MAIRCA model: A case study in pharmaceutical supplying in Libya. Decis. Mak. Appl. Manag. Eng.2018;1(2):pp. 16-33

[16] Pamučar D, Stević Ž, Sremac S, A New Model for Determining Weight Coefficients of Criteria in MCDM Models: Full Consistency Method (FUCOM). Symmetry. 2018;10(9): p. 393

[17] Liu F, Aiwu G, Lukovac V, Vukic M, A multicriteria model for the selection of the transport service provider: A single valued neutrosophic DEMATEL multicriteria model. Decis. Mak. Appl. Manag. Eng. 2018;1(2): pp. 121-130

[18] Bojanić D, Kovač M, Bojanic M, Ristic V, Multi-criteria decision making in defensive operation of guided anti-tank missile battery: An example of hybrid model fuzzy AHP-MABAC. Decis. Mak. Appl. Manag. Eng. 2018;1(1): pp. 51-66

[19] Pehlivan NY, Şahin, A., Zavadskas, E. K., \& Turskis, Z. A comparative study of integrated FMCDM methods for evaluation of organizational strategy development. J. Bus. Econ. Manag.2018;19(2):pp. 360-381

[20] Zavadskas EK, Turskis Z, Simona Kildiene S. State of art surveys of overviews on MCDM/MADM methodsTechnol. Econ. Dev. Eco. 2014;20(1): pp.165-179

[21] Saaty TL. The analytic hierarchy process. New York (US): McGraw-Hill; 1980

[22] Radwan NM, Badr Senousy M, Riad AEDM. Neutrosophic AHP Multi Criteria Decision Making Method Applied on the Selection of Learning Management System. Int. J. Adv. Comput. Technol. 2016;8(5): pp. 95-105

[23] Van Laarhoven PJM, Pedrycz W. (1983). A fuzzy extension of Saaty's priority theory. Fuzzy. Sets. Syst.1983;11: pp. 229-241

[24] Zhu GN, Hu J, Qi J, Gu CC, Peng YH. An integrated AHP and VIKOR for design concept evaluation based on rough number. Adv. Eng. Inform. 2015;29(3): pp. 408-418

[25] Brans JP. L'ingénièrie de la décision; Elaboration d'instrumentsd'aide à la décision. La méthode PROMETHEE. In: Nadeau R and Landry M (eds). L'aide à la décision: Nature,Instruments et Perspectives d'Avenir. Presses de l'Université Laval: Quebec, 1982; pp. 183-214

[26] Behzadian M, Kazemzadeh RB, Albadvi A, Aghdasi M. PROMETHEE: A comprehensive literature review on methodologies and applications. Eur. J. Oper. Res. 2010;200(1): pp. 198-215 
[27] Vasiljević M, Fazlollahtabar H, Stević Ž, Vesković S. A rough multicriteria approach for evaluation of supplier criteria in automotive industry. Decis. Mak. Appl. Manag. Eng. 2018;1(1): pp. 82-96

[28] Stević Ž, Pamučar D, Vasiljević M, Stojić G, Korica S. Novel integrated multi-criteria model for supplier selection: Case study construction company. Symmetry. 2017;9(11): p. 279

[29] Liu D, Yuan Y, Liao S. Artificial neural network vs. nonlinear regression for gold content estimation in pyrometallurgy. Expert Systems with Applications, 2009;36(7): pp. 10397-10400

[30] Nikolic D, Milosevic N, Zivkovic Z, Mihajlovic I, Kovacevic R., Petrovic, N. Multi-criteria analysis of soil pollution by heavy metals in the vicinity of the Copper Smelting Plant in Bor (Serbia). J. Serb. Chem. Soc. 2011;76(4): 625-641

[31] Azadeh A, Izadbakhsh HR. A MULTI-VARIATE/MULTI-ATTRIBUTE APPROACH FOR PLANT LAYOUT DESIGN. Int. J. Ind. Eng.Theory Appl. Pract. 2008;15(2): pp. 143-154

[32] Soota T, Singh H, Mishra RC. Selection of Curricular Topics Using Framework for Enhanced Quality Function Deployment. Int. J. Ind. Eng.Theory Appl. Pract. 2009;16(2), pp. 108-115

[33] Nikolić D, Milošević N, Živkovic Ž, Mihajlović I, Kovačević R, Petrović N. Multi-criteria analysis of soil pollution by heavy metals in the vicinity of the Copper Smelting Plant in Bor (Serbia). J. Serb. Chem. Soc. 2011;76(4): pp. $625-641$

[34] Milijić N, Mihajlović I, Nikolić D, Živković Ž. Multicriteria analysis of safety climate measurements at workplaces in production industries in Serbia. Int. J. Ind. Ergon. 2014;44: pp. 510-519

[35] Higgins DR, Gray NB, Davidson MR. Simulating particle agglomeration in the flash smelting reaction shaft. Miner. Eng. 2009;22: pp. 1251-1265

[36] Vračar R. Theory and practice of non-ferrous metals. Belgrade (RS): Association of metallurgical engineers of Serbia; 2010 (In Serbian)

[37] Jian-hua L, Wei-hua G, Yong-fang X, Chun-hua Y. Dynamic modeling of copper flash smelting process at a Smelter in China. Appl. Math. Modell. 2014;38: pp. 2206-2213

[38] Outokumpu: http://www.outokumpu.com/en/company/history/Pages/default.aspx

[39] Outotec: http://new.outotec.com

[40] USGS: https://mrdata.usgs.gov/mineral-resources/copper-smelters.html

[41] Najdenov I, Rai K, Kokeza G. Aspects of energy reduction by autogenous copper production in the copper smelting plant Bor. Energy. 2012;43: pp. 376-384 
[42] Isasmelt: http://www.isasmelt.com/EN/technology/Pages/Technology.aspx 2017

[43] Queneau PE, Marcuson SW. 1996. Oxygen pyrometallurgy at copper cliff-a half century of progress. JOM-J MET. 48(1): pp. 14-21

[44] Kapusta JPT. JOM World Nonferrous Smelters Survey, Part I: Copper. JOM. 2004;56(7): pp. 21-27

[45] Inco: http://www.inco.com.tr/about.php 2017

[46] Shibasaki T, Hayashi M, Nishiyama Y. 1993. Recent operation at Naoshima with a larger Mitsubishi furnace line, in: C. Landolt (Ed.). Extractive Metallurgy of Copper, Nickel and Cobalt (the Paul E. Queneau International Symposium). Volume II: Copper and Nickel Smelter Operations TMS, Warrendale, PA, pp. 1413-1428

[47] Asaki Z, Taniguchi T, Hayashi M. Kinetics of the reactions in the smelting furnace of the Mitsubishi process. JOM. 2001;53(5): pp. 25-27

[48] Wang JL, Chen YZ, Zhang W, Zhang CF. Furnace structure analysis for copper flash continuous smelting based on numerical simulation. Trans. Nonferrous Met. Soc. China. 2013;23(12): pp. 3799-3807

[49] Iida O, Hayashi M, Goto M. Process designs on new smelter projects of the Mitsubishi continuous copper smelting and converting process. In: Proceedings of the Nickel-Cobalt 97 International Symposium, vol. 3, 1997 August 17-20, Sudbury, Canada: pp. 499-511

[50] Fthenakis V, Wang W, Kim HC. Life cycle inventory analysis of the production of metals used in photovoltaics. Renewable Sustainable Energy Rev. 2009;13: pp. 493-517

[51] Veldhuizen H, Sippel B. Mining discarded electronics. Industry and Environment. 1994;17(3): pp. 7-11

[52] Cui J, Zhang L. Metallurgical recovery of metals from electronic waste: A review. J. Hazard. Mater. 2008;158: pp. 228-256

[53] Schaaf M, Gómez Z, Cipriano A. Real-time hybrid predictive modeling of the Teniente Converter. J. Process Control. 2010;20(3): pp. 3-17

[54] Bergh LG, Chacana P, Carrasco C. Control strategy for a Teniente Converter. Miner. Eng. 2005;18 (11): pp. 1123-1126

[55] Valencia A, Rosales M, Paredes R, Leon C, Moyano A. Numerical and experimental investigation of the fluid dynamics in a Teniente type copper converter. Int. Commun. Heat Mass Transfer. 2006;33 (3): pp. 302-310

[56] Najdenov I. Managing copper smelting and rafination processes for improving energy efficiency and economic feasibility. Belgrade (RS): University of Belgrade, Faculty of Technology and Metallurgy; 2013 (In Serbian) 
[57] Ullmann F. Ullmann's Encyclopaedia of Industrial Chemistry, $7^{\text {th }}$ ed., Wiley-VCH, Weinheim. 1995; pp. 471-524

[58] Mohagheghi M, Askari M. 2016. Copper recovery from reverberatory furnace flue dust. Int. J. Miner. Process. 2016;157: pp. 205-209

[59] Stanković Ž. Management of technological innovations in metallurgy of heavy non-ferrous metals. Bor: RTB Bor and Mining and Metallurgy Institute Bor; 2000

[60] Diaz C, Landolt C, Luraschi A, Newman CJ. Pyrometallurgy of copper. Volume IV. New York (US): Pergamon Press; 1991

[61] Davidović A, Najdenov I, Husović Volkov T, Raić TK. Induction Furnace without Core: Design, Operating Parameters and Applications. Livarstvo. 2009;48(2): pp. 12-23

[62] Biswas AK, Davenport WG. Extractive Metallurgy of Copper (Third edition). Great Britain: British Library; 1994

[63] Davenport WG, Jones DM, King MJ, Partelpoeg EH. Flash Smelting: Analysis, Control and Optimization. TMS (The Minerals, Metals and Materials Society), Warrendale. PA; 2001

[64] Kazem S, Hadinejad F. PROMETHEE technique to select the best radial basis functions for solving the 2-dimensional heat equations based on Hermite interpolation. Eng. Anal. Boundary Elem. 2015;50: pp. 29-38

[65] Bagherikahvarin M, De Smet Y. A ranking method based on DEA and PROMETHEE II (a rank based on DEA \& PR.II). Measurement. 2016;89: pp. 333-342

[66] Figueira J, Greco S, Ehrogott M. Multiple Criteria Decision Analysis, State Of The Art Survey. New York (US): Springer Science; 2005

[67] Abedi M, Torabi SA, Norouzi GH, Hamzeh M, Elyasi GR. PROMETHEE II: a knowledge-driven method for copper exploration. Comput. Geosci. 2012;46: pp. 255-263

[68] Kadziński M, Ciomek K. Integrated framework for preference modeling and robustness analysis for outranking-based multiple criteria sorting with ELECTRE and PROMETHEE. Information Sciences. 2016;352 (C): pp. $167-187$

[69] Roy B, Vincke P. Multicriteria analyses: survey and new directions. Eur. J. Oper. Res. 1981;8 (3): pp. 207-218

[70] Vetschera R, de Almeida AT. A PROMETHEE-based approach to portfolio selection problems. Computers \& Operations Research. 2012;39 (5): pp. 1010-1020

[71] Peng AH, Xiao XM. Material selection using PROMETHEE combined with analytic network process under hybrid environment. Matererials and Design. 2013;47: pp. 643-652 
[72] Tavana M, Behzadian M, Pirdashti M, Pirdashti H. A PROMETHEEGDSS for oil and gas pipeline planning in the Caspian Sea basin. Energy Econ. 2013; 36: pp. 716-728

[73] Yu X, Xu Z, Ma Y. Prioritized multi-criteria decision making based on the idea of PROMETHEE. Procedia Comput. Sci. 2013;17: pp. 449-456

[74] Zhao H, Peng Y, Li W. Revised PROMETHEE II for Improving Efficiency in Emergency Response. Procedia Comput. Sci. 2013;17: pp. 181-188

[75] Amaral TM, Costa APC. Improving decision-making and management of hospital resources: An application of the PROMETHEE II method in an Emergency Department. Operations Research for Health Care. 2014; 3: pp. $1-6$

[76] Veza I, Celar S, Peronja I. Competences-based Comparison and Ranking of Industrial Enterprises using PROMETHEE Method. Procedia Eng. 2015;100: pp. 445-449

[77] Vego G, Kučar-Dragičević S, Koprivanac N. 2008. Application of multicriteria decision-making on strategic municipal solid waste management in Dalmatia, Croatia. Waste Manage. 20008;28: pp. 2192-2201

[78] Ilić I, Bogdanović D, Živković D, Milošević N, Todorović B. Optimization of heavy metals total emission, case study: Bor (Serbia). Atmos. Res. 2011;101: pp. 450-459

[79] Savic M, Djordjevic P, Mihajlovic I, Zivkovic Z. Statistical modeling of copper losses in the silicate slag of the sulfide concentrate smelting process. Polish Journal of Chemical Technology. 2015;17 (3): pp. 62-69

[80] Brans JP, Mareschal B. The PROMCALC and GAIA decision support system for multicriteria decision aid. Decision Support Systems.1994;12: pp. 297-310

[81] Anand G, Kodali R. Selection of lean manufacturing systems using the PROMETHEE, Journal of Modelling in Management. 2008;3(1): pp. 40-70

[82] Ishizaka A, Nemery P. Selecting the best statistical distribution with PROMETHEE and GAIA. Comput. Ind. Eng. 2011;61(4): pp. 958-969

[83] Djordjević P, Nikolić D, Jovanović I, Mihajlović I, Savić M, Zivković Ž. Episodes of extremely high concentrations of SO2 and particulate matter in the urban environment of Bor, Serbia, Environ. Res. 2013;126: pp. 204-207

[84] Nikolić I, Jovanović I, Mihajlović I, Miljanović I. 2015. Analysis of copper concentrate production by sistemic approach. Copper. 2015;40(2): pp. 3350

[85] Nikolić I, Milošević I, Milijić N, Mihajlović I. Impact on the environment on selection of adequate technology for the copper smelting, Environmental awareness as a universal European Value 2016, Bor, University of Belgrade, Technical Faculty in Bor, Engineering Management Department (EMD). 2016; pp. 168-177

[86] RTB Bor: http://rtb.rs 